\begin{tabular}{|c|c|c|}
\hline KULTURA & $\begin{array}{l}\text { POLSKA AKADEMIA NAUK } \\
\text { KOMITET SOCJOLOGII } \\
\text { INSTYTUT STUDIÓW POLITYCZNYCH }\end{array}$ & ISSN 0023-5172 \\
\hline & NOWE MECHANIZMY WYTWAR & NIA KULTUR \\
\hline
\end{tabular}

KRZYSZTOF ABRISZEWSKI

Uniwersytet Mikołaja Kopernika w Toruniu

\title{
UCZESTNICTWO JEDNOSTEK W KULTURZE \\ UWAGI NA TEMAT NOWEJ DYNAMIKI KULTURY NA PRZYKŁADZIE MELOMANÓW I EWOLUCJI NOŚNIKÓW MUZYKI*
}

\section{OGÓLNY ZAMYSŁ ROZWAŻAŃ}

Ktoś, kto próbuje podjąć zagadnienie nowych mechanizmów wytwarzania kultury wprost, powinien albo od razu zabrać się za pisanie grubej książki, albo liczyć się ze spektakularną porażką. O wiele lepszą strategią, pozalającą uchwycić problem, wydaje się jego sprofilowanie. Chciałbym więc podjąć zagadnienie nowych mechanizmów wytwarzania kultury, mówiąc o uczestnictwie melomanów w kulturze, w której dokonuje się ciągła ewolucja nośników muzycznych. Ułatwi to ujęcie złożonych kwestii teoretycznych poprzez empiryczne przykłady. Oczywiście, ograniczenie takie stwarza zagrożenie, że zobaczy się zbyt mało.

Pytanie wyjściowe można więc przeformułować tak: Jaka jest dynamika kultury, w której dokonuje się ewolucja nośników muzyki? Można pójść dalej i zadać kolejne pytanie: Co to znaczy ewolucja nośników? Pojawia się następne pytanie - na czym polega i gdzie dokonuje się ewolucja nośników? Odpowiedzi na te pytania chcę udzielić odwołując się do etnograficznych badań prowadzonych $\mathrm{w}$ grupie melomanów, to znaczy osób, dla których kolekcjonowanie muzyki (a precyzyjniej, muzyki ulokowanej na jakichś nośnikach) jest ważnym życiowym projektem. Oparciem dla ścieżki empirycznej jest analiza, którą przeprowadziłem w tekście Przemyst kulturowy jako pole sit. Działania melo-

Adres do korespondencji: krzabr@umk.pl

* Tekst ten narodził się jako zapis uwag przedstawionych w trakcie dyskusji panelowej „Nowe mechanizmy wytwarzania kultury”, która odbyła się podczas XIV Ogólnopolskiego Zjazdu Socjologicznego, Kraków, 8-11 września 2010. Pragnę podziękować wszystkim osobom, które przez udział w niej pomogły mi usprawnić i przemyśleć na nowo te rozważania. 
manów i ewolucja nośników muzycznych (Abriszewski 2010a), a także wynikające $\mathrm{z}$ niej ustalenia.

Ta ścieżka rozważań ma zapobiegać teoretycznym ekscesom pozbawionym odniesienia. Chciałbym jednak przedstawić szereg teoretycznych postulatów dotyczących mechanizmów wytwarzania współczesnej kultury. Uwagi teoretyczne wywodzą się z przede wszystkim ze studiów nad nauką i technologią (STS), których pewne, bardzo ogólne rozstrzygnięcia spróbuję przenieść na obszar badania kultury. Wybór zaplecza teoretycznego można uzasadnić tym, że STS-y intensywnie rozwijają się w ostatnich trzydziestu, czterdziestu latach, przełamawszy kilka poważnych przeszkód. Część z nich dotyczyła empirycznego badania zjawisk z zakresu nauki i technologii ${ }^{1}$. Przełamały również teoretyczne ograniczenia, które na przykład przyjmowały formę przedzałożenia, że kwestii czysto technicznych (budowa pocisków rakietowych, konstrukcja akumulatorów w samochodach elektrycznych, konstrukcja pompy wodnej, procedury operowania $\mathrm{w}$ przypadku arteriosklerozy kończyn dolnych czy łączenie wagoników w kolejce miejskiej ${ }^{2}$ ) nauki społeczne nie są w stanie ująć, że zatrzymują się na ich symbolicznym wymiarze, pozostawiając przyziemną materialną rzeczywistość inżynierom czy po prostu „twardszym” naukom.

\section{ZASTRZEŻENIA}

Nakreśliłem już ogólny zamysł - przedstawić nowe, współczesne mechanizmy tworzenia kultury z perspektywy uczestniczenia w niej (jako meloman i jako badający melomanów). Należy przy tym dodać przynajmniej dwa istotne zastrzeżenia.

Pierwsze: otwarte pozostaje pytanie, w jakim stopniu to, co przedstawię, ukazuje nowe mechanizmy kulturowe, w jakim zaś stanowi rezultat zastosowania nowych narzędzi analitycznych? Pozostaje jeszcze trzecia możliwość wypadkowa obu. Problem wydaje się o tyle złożony, że jedną z postulowanych cech kultury ma być jej refleksyjność ${ }^{3}$, dokonująca się między innymi poprzez rozmaite systemy eksperckie (por. Giddens 2008; Beck, Giddens, Lash 2009). Można rozsądnie argumentować, że choć kultura współczesna systemów eksperckich nie wynalazła, to procesy modernizacyjne niezwykle je rozmnożyły. Co prowadzi do dalszej konkluzji: być może mechanizmy modernizacyjne, a wraz z nimi rozpowszechnienie się systemów eksperckich, jako jednocześnie rezultat wykorzenienia i napęd wtórnego zakorzenienia, spowodowały mnożenie się

${ }^{1} \mathrm{Na}$ ten temat zob. np. szersze omówienia historyczne studiów nad nauką i technologią w Golinski 2005; Zammito 2004.

2 Kwestie te są omawiane w kolejno: McKenzie 1990; Callon 1986; de Laet, Mol 2000; Mol 2002; Latour 1996.

$3 \mathrm{~W}$ literaturze znaleźć można rozróżnienia między refleksyjnością a refleksywnością. Kwestię tę pomijam tutaj jako marginalną dla moich rozważań i w całym tekście posługuję się określeniem „refleksyjność”. 
na niezwykłą skalę zjawisk w kulturze, które nie wpisują się w tak czy inaczej uporządkowany obraz naszego świata.

Przywołajmy pewien model, aby rozbudować tę tezę. W książce pod tytułem Nigdy nie byliśmy nowocześni Bruno Latour (2011) kreśli obraz nowoczesności jako pewnego projektu, który został nałożony na różną od niego faktyczną dynamikę zbiorowego życia. Projekt ów nosi nazwę Nowoczesnej Konstytucji. Jego cechą charakterystyczną jest rozdzielenie zbiorowego świata na dwa bieguny: naturę i kulturę - opozycja, która stanie się podstawowym schematem wszelkich działań społecznych oraz podstawą wartościowania innych kultur. Podczas gdy według Nowoczesnej Konstytucji wszelkie zjawiska są albo kulturowe (społeczne, polityczne), albo naturalne (przyrodnicze), to faktyczny tryb zachodzenia zbiorowych innowacji angażował zawsze i jednocześnie zróżnicowane ontologicznie czynniki. Konsekwencją zapanowania Nowoczesnej Konstytucji jest niekontrolowana proliferacja hybryd (zob. Abriszewski 2008, s. 289-304). Najprościej mechanizm ten widać w przypadku innowacji naukowo-technicznych. Instytucje polityczne w żadnej mierze nie usiłują kontrolować wynalazków, które mają wejść w obieg zbiorowości, albo czynią to bardzo rzadko. Reagują po fakcie (jak w przypadku rozmaitych alarmów ekologicznych czy katastrof przemysłowych).

Ten bardzo uproszczony schemat nasuwa następujący wniosek: kultura bez Nowoczesnej Konstytucji jest bardziej ustabilizowana, ponieważ nie posiada mechanizmu szybkiego i niekontrolowanego mnożenia się hybryd. Co oznacza, że każda zmiana wymaga silnej kulturowej sankcji. Jednakże kultura z Nowoczesną Konstytucją sama sobie wydaje się znacznie lepiej uporządkowana niż kultury nie-nowoczesne (por. Latour 2011), ponieważ nie potrafią one tak dobrze jak ta pierwsza rozróżniać zjawisk kulturowych i przyrodniczych (na przykład nie potrafią oddzielić wierzeń i mitów na temat ciał niebieskich od przyrodniczych obiektów astronomicznych albo oddzielić rzeczywistej historii zdarzeń religijnych od wierzeń i przekonań światopoglądowych). Dlatego może ona poszukiwać ładu, o jakim pisze Zygmunt Bauman (2000, s. 185-186) usiłuje na przykład wskazać, jakie wartości są dla niej centralne, a wszelkie wartości w ogóle stara się ułożyć w raz na zawsze gotową hierarchię.

Tymczasem poniżej poziomu projektu, jakim jest Nowoczesna Konstytucja, trwa niekontrolowane, nieustannie namnażanie się hybryd, co coraz częściej zaczyna prowadzić do nieprzewidzianych konsekwencji. Konsekwencje takie Michel Callon, Pierre Lascoumes i Yannick Barthe (2009) określają jako overflows, a ja nazywam anomaliami. Anomalie te to nic innego, jak różne lokalne zapaści porządku Nowoczesnej Konstytucji, które przyjmują postać nieoczekiwanego mieszania się zjawisk przypisywanych do opozycyjnych biegunów.

Moje przypuszczenie byłoby więc następujące: żyjemy w kulturze coraz większej liczby anomalii. To zaś oznacza, że nasze zainteresowania badawcze powinny zostać także przeniesione $z$ obszarów stabilizacji i ładu na obszary 
nieładu, bałaganu i anomalii właśnie. Tym samym mówienie o nowych mechanizmach wytwarzania kultury i nowych sposobach ich ujmowania przestaje dotyczyć dychotomii według zasady rozdziału narzędzi i obszaru ich zastosowania. Stosowalność bowiem nowych narzędzi sama stanowi część charakterystyki nowej dynamiki kulturowej. Jeśli zaś mam rację, to poniżej powinienem mówić o obu zakresach jednocześnie.

Drugie zastrzeżenie: zawsze istnieje możliwość, że przedstawione rozważania nie wniosą nic nowego, ponieważ reinterpretacja myśli starszych badaczy i autorów wykazałaby rozpoznawanie tych samych mechanizmów. Być może „Wszystko wiadomo od Platona”, ale z jakiegoś powodu autor sobie tego nie uświadamiał. Pod tym względem mogę jedynie prosić czytelnika o życzliwość i wyrozumiałość. Próby chwytania tego, co nowe skazane są (często? zawsze?) na ryzyko balansowania między niezrozumiałością z jednej strony a banałem i oczywistością z drugiej.

W swoich rozważaniach na początku omówię zaproponowaną przez Marka Krajewskiego (2010) reinterpretację pojęcia uczestnictwa w kulturze, co pozwoli na zogniskowanie dalszych uwag właśnie wokół kategorii uczestnictwa. Następnie chciałbym przyjrzeć się pojęciu kultury, tak aby wyzyskać przynajmniej trzy różne ścieżki czy tradycje myślowe. Na koniec chciałbym wskazać na elementy nowej dynamiki kultury, posiłkując się odwołaniami do moich badań nad melomanami.

\section{UCZESTNICTWO W KULTURZE}

Marek Krajewski rozpoczął od krytycznych uwag pod adresem tradycyjnie pojmowanego uczestnictwa w kulturze. Wskazał założenia wpisywane w tę kategorię. Pierwsze, mówiące o tym, że wzrost poziomu uczestnictwa przekłada się na poprawę poziomu życia, można nazwać założeniem uwznioślania większy udział w kulturze to lepsze życie, mniejszy to życie gorsze. Oznacza to, że optymalnie człowiek powinien zostać zanurzony w zjawiskach kulturalnych pojmowanych — i tu drugie założenie — komunikacyjnie (mierzenie poziomu czytelnictwa byłoby tu przypadkiem wzorcowym). Trzecie założenie, wiążące się z komunikowaniem ku uwznioślaniu, dotyczy ideału istoty zamieszkującej kulturę w sposób optymalny — jest nim intelektualista.

Zygmunt Bauman (2000, s. 185), idąc podobnym tropem, w tekście Kultura jako spótdzielnia spożywców rozróżnia dwie formuły pojęcia „kultura” - hierarchiczną i różnicującą. Założenia wskazane przez Krajewskiego całkowicie wpisują się w hierarchiczny model kultury. Jego istotną częścią jest założenie, że kultura ma dwudzielną strukturę, co rozbija zbiorowy świat na wiedzących/nauczycieli (czy intelektualistów) i tych, których trzeba nauczyć, którzy dopiero aspirują (Bauman 2000, s. 183). Można jednak zapytać, idąc tropem obu socjologów, w jakim stopniu taki model jest użyteczny przy badaniu zbiorowej rzeczywistości? W jakim stopniu jest adekwatny? Obaj odpowiadają, że 
model jest niedobry lub, przynajmniej, że wyczerpał swój potencjał poznawczy i obecnie więcej maskuje niż ukazuje.

Bauman (2000) proponuje $\mathrm{w}$ to miejsce pojmowanie kultury jako spółdzielni spożywców, w której toczą się procesy nie do końca żywiołowe i nie do końca sterowane. W której każdy jest wytwórcą i konsumentem. W której potrzeby wytwarzane są wraz z mechanizmami ich zaspokajania. W tak rozumianej kulturze nie istnieje żadna stała struktura, lecz jedynie rozmaite procesy różnicujące, które lokalnie strukturyzują (Bauman 2000, s. 189-198). Do tego obrazu można dodać, jako uzupełnienie, redefinicję pojęcia uczestnictwa zaproponowaną przez Krajewskiego (2010), ponieważ znakomicie wpasowuje się ona w dynamiczną, producencko-konsumencką i wielowymiarową wizję Baumana.

Według pierwszego najogólniejszego przybliżenia, uczestnictwo oznacza włączenie (się) jakiegoś elementu w sytuację kulturowo uregulowaną. Tutaj dodajemy jednakże ważne uzupełnienie - uczestniczenie oznacza wzięcie udziału w czymś, co ma charakter otwarty, niedomknięty, niedopełniony, co jest niegotowe, a co trzeba przez własne uczestnictwo współtworzyć (producenci-konsumenci Baumana). W rezultacie dochodzi do zmiany zastanego kontekstu, co może oznaczać nawet zmianę wszystkich wchodzących w grę elementów (lokalne strukturyzowanie).

Mając tak zarysowany ogólny obraz uczestnictwa, możemy wyodrębnić jego trzy wymiary:

1. Uczestniczenie staje się procesem uspołeczniania. Poprzez uczestniczenie może następować wiązanie ze sobą ludzi i rzeczy (czynników pozaludzkich - ang. nonhumans ${ }^{4}$ ) na rozmaite sposoby. W rezultacie może dojść do tworzenia się mniej lub bardziej stabilnych sieci relacji, przy czym stabilizowanie takich nowych konfiguracji także jest uczestniczeniem.

2. Uczestniczenie pociąga za sobą przekształcanie elementów, które wcho$\mathrm{dzą} \mathrm{w}$ relacje. Wchodzenie $\mathrm{w}$ relacje pozostawia materialny ślad, który można tropić. Tym samym wchodzenie w relacje oznacza działanie, którego rezultaty przekładają się na działanie innych (ludzi i rzeczy) ${ }^{5}$.

3. Uczestnictwo oznacza także swoiste „metauczestnictwo”, to znaczy wpływa na warunki sytuacji uczestnictwa, modyfikuje je, wpływa na reprodukcję stanu rzeczy, jego stabilizację (jak wskazałem w punkcie 1). Mówiąc językiem Bourdieu, uczestnictwo oznacza „bycie w grze” wraz z koniecznością inwestowania i reinwestowania w pozostawanie w grze (zob. Bourdieu, Wacquant 2001, s. 78-81; por. Jacyno 1997, s. 23-36).

Uważny czytelnik prawdopodobnie rozpoznał już wątki zaczerpnięte z STS-ów. Chciałbym poprowadzić je jeszcze dalej. Z mojego punktu widzenia, za-

\footnotetext{
4 Taki sposób przekładu pojęcia nonhumans wyjaśniam w: Abriszewski 2010a, s. XXX-XXXI.

5 Na temat działań zob. Latour 1999, s. 113-144 (zwłaszcza s. 119-123); Abriszewski 2008, s. $67-74$.
} 
proponowana przez Krajewskiego redefinicja „uczestniczenia” znakomicie pozwala zastosować polskie pojęcie, które dobrze zastąpi pojęcia występujące w STS-ach i sprawiające kłopot przy próbach precyzyjnego przekładu. Myślę tu o takich pojęciach, jak practice, perform, act, enact (zob. np. Mol 2002). Polskie „działanie” zdecydowanie tutaj nie wystarczy. Tymczasem zastosowanie zreinterpretowanej kategorii uczestnictwa w części pozwala na uzyskanie takiego sensu jak w przypadkach posłużenia się $\mathrm{w}$ tekstach anglojęzycznych słowem perform i enact.

Jako ilustrację chciałby wykorzystać tytuł książki Acting in an Uncertain World Michela Callona, Pierre'a Lascoumesa, Yannicka Barthe'a (2009). Oczywiście, można oddać go jako „działanie w niepewnym świecie”, ale powiedzenie „uczestniczenie w niepewnym świecie” w trybie zaproponowanej redefinicji od razu wrzuci nas w sam środek problematyki książki: Jaki charakter ma wiązanie się $z$ innymi w niepewnym świecie? Co zmieniamy i co chcemy zmieniać uczestnicząc $w$ niepewnym świecie? Jaki pożądany przyszły stan świata chcielibyśmy wytworzyć uczestnicząc $\mathrm{w}$ niepewnym świecie?

Ta prosta zabawa tytułem miała zilustrować dwie kwestie. Przede wszystkim istotność redefinicji pojęcia uczestnictwa, zaproponowanej przez Krajewskiego $\mathrm{w}$ innym kontekście, i zasadność powiązania go $\mathrm{z}$ dorobkiem $\mathrm{z}$ zakresu studiów nad nauką i technologią. Miała też pokazać, że przejście od starych definicji uczestnictwa, w znacznej mierze już zdroworozsądkowych, w stronę ponownej technicznej redefinicji tego pojęcia daje zysk poznawczy. Innymi słowy, udziwnienie pojęcia „uczestnictwo” przez zanurzenie go w określonym kontekście teoretycznym pozwala zobaczyć znacznie więcej.

A co z pojęciem kultury?

\section{WYMIARY POJĘCIA „KULTURA”}

W przypadku pojęcia kultury musimy postąpić podobnie jak z pojęciem uczestnictwa - rozbić je na kilka istotnych dla nas wymiarów i pozostawić na boku całą złożoność i historyczne nasycenie tej kategorii. Pod pewnymi względami konieczność posłużenia się tym pojęciem jest niewygodna. Tak bardzo się ono rozszerzyło i rozmyło, że przypuszczalnie straciło jakąkolwiek moc wyjaśniającą ${ }^{6}$. Jednakże jeśli mamy mówić o uczestnictwie w kulturze, to nie sposób je ominąć, uciekając się do tłumaczenia, że możemy przeprowadzić wyjaśnianie na bardziej szczegółowym poziomie. Toteż jedynym wyjściem jest, podobnie jak w przypadku uczestnictwa, próba wyjęcia pojęcia „kultura" z trybu potocznego i przeniesienie go w bardziej złożony kontekst teoretyczny.

\footnotetext{
${ }^{6}$ Książka Adama Kupera (2005) jest w tej mierze niezwykle instruktywna — autor śledzi koleje losu pojęcia kultury od jego wyłonienia się poprzez rozmaite socjologiczne i antropologiczne uwikłania.
} 
Chciałbym zatem wskazać na trzy wymiary kultury, które powinniśmy brać pod uwagę, gdy mówimy o uczestnictwie w kulturze:

1. Kultura jest tym, co umożliwia uczestnictwo i w obrębie czego uczestnictwo się odbywa. Ten wymiar odnosi się do chyba najbardziej rozpowszechnionego myślenia o kulturze, bliskiego podzielenia mapy na kolorowe kształty oznaczające państwa. Kultury też są takimi obszarami obowiązywania, które ze sobą sąsiadują. W tradycji późnonowożytnej filozofii niemieckiej mówi się o duchu - duchu narodu, duchu miejsca, duchu czasów. Jednostki ludzkie żyją w obrębie oddziaływania owego ducha (por. Kuper 2005, s. 26-32). To właśnie ta tradycja myślenia o kulturze jako „pojemniku”, w którym się znajdujemy i jako zespole warunków, które owo uczestnictwo umożliwiają. Ta sama tradycja, na przykład w antropologicznej szkole Boasa, mówi o relatywizmie (poznawczym, językowym) i w różnych konfiguracjach kulturowych każe widzieć odmienne predefiniowanie sytuacji poznawczych.

2. Kultura jest zasobem, którym operuje się w trakcie uczestnictwa. „Kultura" jest pojęciem abstrakcyjnym, to znaczy nie jesteśmy w stanie przeprowadzić jej definicji ostensywnej (powiedzieć „to jest kultura”, wskazując na coś), co najwyżej możemy mówić „to należy do kultury”. To oznacza, że pojęcie to zawsze przekracza nasz horyzont poznawczy. Jednocześnie tacy badacze jak Kirsten Hastrup (2008) wskazują tę samą cechę, podkreślając inną konsekwencję - kultura, ponieważ jest abstrakcją, powstaje w procesie abstrahowania. Takim procesem jest spisywanie raportu przez badacza. To właśnie $\mathrm{w}$ toku sporządzania raportu naukowego zestawienie rozmaitych zjawisk, uogólnienie ich, opisanie i wyjaśnienie, prowadzi do nałożenia etykietki „kultura” (lub jakiejś pokrewnej, jak „wzorce kulturowe”, „tradycja” itp.; por. Hastrup 2008; Latour 2010, s. 173-201). Kultury wyłaniają się więc jako zawsze usytuowane rezultaty pracy badawczej, która związała $\mathrm{w}$ jedno rozmaite elementy ( $\mathrm{w}$ toku badań). Tak uzyskana kultura może z kolei stać się elementem codziennych interakcji, przedmiotem sporów, obszarem planowania, może zostać poddana rewizji czy ocenie.

3. Kultura wyłania się w toku uczestnictwa. Pod tym względem z kolei odwołujemy się do tradycji nurtów interakcyjnych, zwłaszcza etnometodologii (Garfinkel 2007) i fenomenologii społecznej (Berger, Luckmann 1986), ale również do uwag Ludwika Flecka (1986) o wyłanianiu się stylu myślowego w toku interakcji. To właśnie $\mathrm{w}$ obrębie tych nurtów wskazywano i podkreślano, że zjawiska ponadjednostkowe, na przykład struktura społeczna, stanowią wynik komunikacyjnych działań jednostek, które wzajemnie przekonują siebie o trwałości ontologicznego (lub po prostu społecznego) ładu.

Możemy teraz $\mathrm{w}$ prosty sposób połączyć pojęcie uczestnictwa $\mathrm{z}$ wymiarami pojęcia kultury. Kultura umożliwia uczestnictwo, a samo uczestnictwo jest kulturowo regulowane, to znaczy odbywa się w przestrzeni (materialnej, symbolicznej) kulturowo predefiniowanej. Kultura jest zasobem, którym posługują się uczestnicy, choćby $\mathrm{w}$ takim sensie, $\mathrm{w}$ jakim usiłują nadać 
sens swemu uczestnictwu. Wreszcie, kultura wyłania się w toku uczestnictwa, ponieważ uczestnicy (re)definiują relacje wiążące ludzi i rzeczy (czynniki pozaludzkie), przeobrażają innych uczestników, modyfikują warunki uczestnictwa.

Widać więc, że w pewnych zakresach trzy wymiary pojęcia kultury naturalnie splatają się z kategorią uczestnictwa. Interesujące byłoby prześledzenie systematycznego i analitycznego skrzyżowania wymiarów obu pojęć i postawienie pytania o to, co dzieje się w miejscach nakładania się danych wymiarów.

Skrzyżowanie wymiarów uczestnictwa i kultury

\begin{tabular}{|c|c|c|c|c|}
\hline & \multicolumn{3}{|c|}{ Kultura } \\
\hline & & $\begin{array}{l}\text { 1. To, co umożliwia } \\
\text { uczestnictwo i w ob- } \\
\text { rębie czego się ono } \\
\text { odbywa }\end{array}$ & $\begin{array}{l}\text { 2. Zasób, którym } \\
\text { operuje się w trakcie } \\
\text { uczestnictwa }\end{array}$ & $\begin{array}{l}\text { 3. To, co wyłania się } \\
\text { w toku uczestnictwa }\end{array}$ \\
\hline \multirow{3}{*}{ 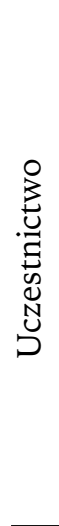 } & $\begin{array}{l}\text { 1. Wiązanie ludzi } \\
\text { i rzeczy w sieć re- } \\
\text { lacji }\end{array}$ & & & \\
\hline & $\begin{array}{l}\text { 2. Przeobrażanie } \\
\text { wszystkich ele- } \\
\text { mentów uczest- } \\
\text { niczących }\end{array}$ & & & \\
\hline & $\begin{array}{l}\text { 3. Reprodukowa- } \\
\text { nie i modyfiko- } \\
\text { wanie sytuacji u- } \\
\text { czestnictwa }\end{array}$ & & & \\
\hline
\end{tabular}

Takie skrzyżowanie wymiarów pojęć pozwala powrócić do uwag wyjściowych: czy we wcześniejszych sposobach pojmowania uczestnictwa i kultury część pól była uprzywilejowana (w sensie angażowania zainteresowań badaczy), podczas gdy inne pozostawały zmarginalizowane? Jeśli tak, to dlaczego tak się działo? Czy na przykład pojawiały się sytuacje operowania pojęciem kultury jako zasobu (kultura 2) po to, by w określony sposób reprodukować sytuację uczestnictwa (uczestnictwo 3)? Czy były one badane? Czy traktowano je jako udział w kulturze, czy jako zjawisko innego rodzaju?

Postawienie takich pytań oznacza przejście od rozważań metapoziomowych, dotyczących sposobów mówienia o kulturze i uczestnictwie, na poziom dynamiki samej kultury i jej badań. Czas więc, aby zapytać o nowe mechanizmy wytwarzania kultury, pamiętając przy tym o złożoności tej kategorii i o wielowymiarowości pojęcia uczestnictwa. 


\section{NOWA DYNAMIKA KULTURY}

Jak już zaznaczałem, musimy przyjąć jakieś wyjściowe ograniczenia, jakąś perspektywę. Chciałbym, żeby stało się nią uczestnictwo, a dokładniej podwójne moje uczestnictwo jako badacza zgłębiającego sposoby życia i realizacji projektów życiowych melomanów oraz moje uczestnictwo jako melomana. Należy pamiętać bowiem o tym, co Kirsten Hastrup opisała sięgając po metaforę opętania - badacz robiący etnografię nie obserwuje po prostu czegoś jak widz akwarium, on uczestniczy w pewnej rzeczywistości przeżywanej, cieleśnie i mentalnie się do niej nastraja, zmienia siebie po to, by opisać, przeanalizować i wyjaśniać odmienne sposoby życia (zob. Hastrup 2008, s. 21-112). Hastrup owo wejście w skórę uczestnika badanej kultury ilustruje opowieściami o doświadczeniu spotkania $z$ duchem czy rzekomego rzucenia klątwy na nielubianą krowę.

Wychodząc od tej podwójnej perspektywy, chciałbym wskazać na kilka mechanizmów dynamiki kulturowej o szerszym zakresie.

\section{Kultura jako ścieranie się sił}

Zygmunt Bauman (2000) w przywoływanym już tekście dokonuje krytyki postrzegania kultury jako ładu. Wiadomo, iż znaczna liczba jego prac zawiera również krytykę zapędów ładotwórczych kultury nowoczesnej (Bauman 1992; 1995). Jednakże zbyt pochopne byłoby postrzeganie kultury jako po prostu obszaru konfliktów, według wzorów znanych ze starszych sporów w socjologii (np. na linii funkcjonalizm-teorie konfliktu). Rozwój technik komunikacyjnych, rozpowszechnienie się dostępu do nich, a tym samym rozwój sieci komunikacyjnych, zmiana typu więzi społecznej, masowa edukacja i wiele innych czynników - wszystko to spowodowało, że kultura przestała być tworem o klarownym kształcie (jeśli w ogóle kiedykolwiek była) czy łatwej do określenia trajektorii. Zamiast tego, należy widzieć w niej wielość ścierających się sił. Jedynie niektóre $z$ tych starć zamieniają się w konflikty, co nie znaczy, że starcia bez konfliktów nie mają zwycięzców ${ }^{7}$.

Przy takim ujęciu obszary porządku są jedynie wyspami lokalnej i tymczasowej stabilizacji (por. Latour 2010, s. 351-358). Jeśli badacz skupia się na nich, to gubi większą część obrazu. W tym kontekście badacz związany z STS-ami oraz z teorią aktora-sieci, John Law, stawia pytania o bałagan (mess) w naukach społecznych (Law 2004). W jaki sposób nauki społeczne radzą sobie $z$ ujmowaniem nieprzejrzystej rzeczywistości? Jak radzą sobie sami badacze $z$ wchodzeniem w zabałaganiony obszar? Czy nie nazbyt często omijamy bałagan, ponieważ potrafimy badać jedynie obszary stabilizacji i względnego

\footnotetext{
${ }^{7}$ Klasyczną pracą poświęconą wielowymiarowości sytuacji konfliktowych jest Poróżnienie Jeana-François Lyotarda (2010).
} 
porządku, a zatem badamy to, co umiemy, a nie to, co chcemy (czy powinniśmy).

Idąc tym tropem, łatwo byłoby osunąć się w badaniu kwestii ewolucji nośników i melomanów na jedną płaszczyznę, uzasadniając to nawet przy użyciu jakichś ontologicznych argumentów. Wtedy badacz mógłby skupić się jedynie na poziomie globalnym czy makrostrukturalnym i obserwować proces ewolucji nośników muzyki w kulturze. Mógłby podawać porządnie opracowane dane statystyczne, wykreślać krzywe obrazujące procesy i tendencje. W ramach tej opowieści pisałby historię wprowadzania i umierania kolejnych nośników, powtarzając po prostu dane techniczne (taka i taka fabryka w takim i takim roku wyprodukowała płytę kompaktową w ilości itd.).

Inny badacz mógłby ograniczyć się do poziomu tradycyjnie pojmowanego etnograficznego rozpoznawania życia melomanów. Opisywałby ich preferencje, zwyczaje, hierarchie wartości i rozmaite wybory życiowe. Mógłby nawet pójść dalej i, odwołując się do zdobyczy brytyjskich studiów kulturowych, przeanalizować, w jaki sposób melomani negocjują znaczenia pochodzące z szerszej rzeczywistości, na przykład przemysłu kulturowego (zob. np. Fiske 2005, s. 1-4; por. Fiske 1990). Jednak badacz ten przyjąłby pewnego rodzaju szersze tło - techniczne, cywilizacyjne, społeczne, ekonomiczne - na którym dopiero nakreśliłby trajektorie życiowe swoich bohaterów. Byłoby to założenie równoległe do tego, które przyjął wcześniejszy, globalny badacz, gdy uznawał, że „gdzieś tam na dole” odbywają się międzyludzkie interakcje, które wpisują się w jego „szersze” zjawiska.

Jeśli zaś kultura ma zostać potraktowana jako dynamiczny proces ścierania się sił, to nie wolno zakładać gotowego jej kształtu ani istnienia ustrukturyzowanych uprzednio poziomów. Jednym z obszarów jest ewolucja nośników, na którą składają się drobniejsze nurty — procesy technologiczne, zabiegi ekonomiczne, kreślenie ewolucji nośników w mediach. Innym zaś zakresem jest uczestnictwo poprzez kolekcjonowanie, także przyjmujące rozmaite formy (kupowania płyt kompaktowych, zbierania skopiowanych CD-ROM-ów, lokowania plików muzycznych na blogu itd.). Teraz należy zapytać: Jaki kształt przyjmują oba zakresy? Czy i w jaki sposób się ujednolicają? Jak są stabilizowane? Jakiego uczestnictwa wymagają, jakie predefiniują? W jakich miejscach się spotykają? W jakie konflikty wchodzą? Jakie są platformy tych konfliktów? Gdzie odbywa się ewolucja nośników? Gdzie odbywa się kolekcjonowanie?

Bliższa analiza pokazała, że jednoliniowość ewolucji nośników (na zasadzie płyta analogowa $\rightarrow$ płyta kompaktowa $\rightarrow$ pliki komputerowe) jest konstruowana w mediach przez zastosowanie szeregu zabiegów retorycznych. Należały do nich upraszczanie zmian technologicznych (zapominano o taśmach, kasetach, minidyskach), układanie ich w linię i dobieranie danych statystycznych, aby linię tę ilustrowały, patologizowanie odmienności (to, co nie zgadza się $z$ idealnie wyznaczoną linią ewolucji, jest nieistotną patologia), zamienianie przedmiotów opisu (mówienie o ewolucji nośników w Polsce i powoływa- 
nie się na amerykańskie lub brytyjskie statystyki) itd. Nie chcę powiedzieć, że ewolucja nośników nie istniała bądź że była fikcją lub medialnym oszustwem. Utrzymuję jednak, że jak każde zjawisko kulturowe musiała zostać jakoś skonstruowana, a wielość składających się na nią sił jakoś ujednolicona i ustabilizowana.

Jednocześnie obraz działania melomanów okazał się bardzo daleki od takiej liniowości. W jakiejś mierze jednak wpisywali się oni niekiedy $\mathrm{w}$ te zmiany. Wyraźnie widoczne także było napięcie czy poróżnienie (Lyotard 2010) między ich projektami życiowymi (kolekcjonowanie muzyki na płytach) a kształtem samej ewolucji (koniec płyt CD, nowa era plików komputerowych). Jednakże zatarg ten nie miał $\mathrm{w}$ zasadzie płaszczyzny ekspresji, która pozwoliłaby na to, by zamienił się w „ustabilizowany” konflikt. Można oczywiście usiłować rozpoznawać jako konflikt takie zjawiska jak lokalny (w Polsce w ostatnich latach) wzrost sprzedaży płyt kompaktowych czy globalny wzrost sprzedaży płyt analogowych, czy też powracanie niektórych wytwórców sprzętu hi-fi do projektowania nowych modeli odtwarzaczy kompaktowych (po ucieczce na początku wieku w stronę kina domowego). Jednakże zjawiska te dopiero badacz może potraktować jako wyrazy konfliktu, a tym samym dopiero jego raport staje się polem, na którym spotkają się obce siły i wejdą $\mathrm{w}$ konflikt.

\section{Usytuowanie}

Wszystkie zjawiska kulturowe są materialnie usytuowane.

Można oczywiście argumentować — w znacznej mierze zasadnie — że kategoria usytuowania raczej należy do porządku badania kultury niż do porządku jej mechanizmów. Nie chodzi bowiem o to, że kiedyś zjawiska kulturowe były nieusytuowane, ale o to, że na usytuowanie zwraca się uwagę w toku analiz.

Taka argumentacja jest prawdziwa, jednakże pomija ona pewien nieco subtelniejszy aspekt problemu. Krytyka, jakiej Krajewski poddaje tradycyjnie pojmowane uczestnictwo, podobnie jak uwagi Baumana na temat hierarchicznego modelu kultury, jest wymierzona w myślenie dwupoziomowe - nauczyciele i uczniowie, intelektualiści i ci, którzy za nimi podążają. Oznacza to, iż w odniesieniu do zjawisk kulturowych istnieje pewna predefinicja, uprzednie lokalizowanie ich bądź w obrębie pierwszej grupy, bądź drugiej. Przypomina się wielokrotnie dekonstruowana $\mathrm{w}$ literaturze opozycja kultury (sztuki) wysokiej i niskiej (kultury masowej, popkultury, rozrywki). Otóż, dla nas oznacza to, iż nie tylko badacze $\mathrm{w}$ trybie metodologicznym dokonywali takiego rozdziału, co podkreśla Marek Krajewski. Oznacza to również, że świadomość takiej opozycji i umiejętność rozdzielania stanowiły elementy kultury, były rozpowszechnione jako narzędzia klasyfikowania zjawisk (wyjście do teatru jest obcowaniem z kulturą, a czytanie komiksów nie) czy jako środki budowa- 
nia własnej tożsamości (,jako autor powieści SF nigdy nie będę prawdziwym pisarzem").

Żeby sensownie można było mówić o usytuowaniu, uprzedni krajobraz kulturowy musi stać się całkowicie płaski - wszystkie zjawiska, wszystkie starcia sił są sobie „równe”, nierówności zaś pojawiają się w wyniku bieżących (lub wcześniejszych) starć (Callon, Latour 1981; Latour 2010, s. 253-358). I dopiero wtedy usytuowanie zaczyna nabierać znaczenia. Przestajemy bowiem jako badacze klasyfikować zjawiska według przyjętych wcześniej kategorii, a nadstawiamy ucha na klasyfikacje aktorów (Latour 2010, s. 39-172). To samo dotyczy innych uprzednich klasyfikacji, jak wspomniane ontologiczne rozdzielanie poziomów analiz (makro/mikro). I konsekwentnie - usytuowanie oznacza także, że sami aktorzy zaczynają działać w płaskim świecie, w którym konkretne materialne usytuowanie staje się istotne.

Wróćmy do przykładu melomanów i ewolucji nośników. Przede wszystkim można przywołać zadane już pytanie: Gdzie toczy się ewolucja nośników? Gdzie, w sensie materialnym i czasoprzestrzennym, ona przebiega? Część tej ewolucji moi rozmówcy śledzili na sklepowych półkach, borykając się z kłopotami przy próbach zakupu sprzętu hi-fi. Narzekali na przykład na niewielki wybór odtwarzaczy kompaktowych przeznaczonych wyłącznie do płyt CD, na niewielki wybór głośników, na brak gramofonów. Zapytani wyjaśniali, że to rezultat rozpowszechnienia się najpierw kina domowego (powodujący łączenie możliwości odtwarzania CD i DVD w jednym urządzeniu przy obniżeniu jakości dźwięku), a następnie komputeryzacji i rozpowszechnienia się plików muzycznych wraz z dobrym dostępem do internetu. Dalej, ewolucję taką można było, o tym również już mówiłem, śledzić jako zjawisko dyskursywne - w prasie i na stronach internetowych. Inna materialna lokalizacja i inne mechanizmy konstrukcyjne. Jeszcze inny wymiar ewolucja nośników przybierała w przypadku moich rozmówców, którzy na rozmaite sposoby manipulowali dostępnymi nośnikami (lecz ich manipulacje wcale nie układały się w liniową trajektorię).

Co ciekawe, melomanów nie interesowało predefiniowane dzielenie świata na przykład na zjawiska o charakterze makrostrukturalnym i mikrostrukturalnym, czy też z na poziomy kultury wysokiej i niskiej. Pod tym względem znakomicie potrafili materialnie usytuować interesujące ich zjawiska. Widać to wyraźnie w praktykach oporu i realizowania własnych projektów życiowych. Melomani nie zastanawiali się nad nasileniem tendencji do znikania odtwarzaczy, lecz po prostu poszukiwali (często poza swoją miejscowościa) sklepu, który będzie potrafił ich zaopatrzyć (i umożliwić uprzednio odsłuch różnych modeli). Jeśli zżymali się na prasowe tezy o końcu płyty kompaktowej (niektóre wygłaszane bądź zapisywane dobrych kilka lat temu), to oczywiście mogli na stronach internetowych umieścić zjadliwy komentarz, jakich wiele daje się odnaleźć. Jednak równie dobrze mogli skorzystać z plików mp3 (iść zgodnie $z$ ewolucją), aby po ich przesłuchaniu decydować, jakie płyty kupić (iść wbrew ewolucji). 
Widzimy więc, że kategoria usytuowania tak rozumiana zarówno określa praktyczny wymiar działań aktorów, jak i powinna należeć do zasobu narzędzi badawczych.

\section{W kulturze współczesnej zmiany nie toczą się po liniowych trajektoriach}

Być może w celu zilustrowania sieciowości zjawisk kulturowych najlepiej byłoby posłużyć się, na zasadzie figury myślowej, którymś z przykładów systemu chaosu deterministycznego opisywanego przez fizykę. Procesy w kulturze nie mają charakteru liniowego. Liniowe narracje na ich temat zawsze są w jakiś sposób mitologiczne, zamieniają oryginalny kulturowy gąszcz w wyraźną ścieżkę. Zamiast tego za każdym razem mamy do czynienia $z$ gęstymi sieciami procesów, których uczestnicy wytwarzają własne obrazy. W zjawiskach kulturowych, tak jak w układach chaotycznych, jeden drobny element może wpłynąć za duże zmiany końcowych rezultatów. Jednak w przeciwieństwie do modeli chaotycznych na żywej tkance kultury nie daje się przeprowadzać eksperymentów, nie sposób więc tezę tę potwierdzić.

Badani melomani nie reagowali w prosty, powtarzalny sposób na zmiany technologiczne. Ich opowieści nie układają się w ciągi współbieżne wobec takich zmian. Ich projekty życiowe nie odzwierciedlają ani linii: płyta analogowa-płyta kompaktowa-pliki komputerowe, ani żadnej innej. Wszyscy oni czynnie interpretowali zmiany, kontestowali je, wykorzystywali, przystosowywali się do nich.

Podczas gdy liniowość ewolucji była tworzona w dyskursie internetowym na przykład w takich wypowiedziach: „Tak jak kompakt wyparł płyty winylowe, tak internetowe zakupy piosenek "na sztuki» wyprą wkrótce kompakty", melomani wypracowywali własne konteksty uczestnictwa. Niektórzy z moich rozmówców starali się nie zauważać istnienia plików komputerowych, inni czynnie $z$ nich korzystali, orientując się dzięki nim, co warto kupić na płytach kompaktowych. Jeszcze inni rzeczywiście dokonywali czegoś na kształt skoku od kompaktów (a częściej CD-ROM-ów) do plików komputerowych, ale jednocześnie zaczynali kolekcjonować płyty winylowe. Wielu podkreślało, że zbieranie kaset to ważny etap. Część z nich w ostatnich latach powraca do kaset, podczas gdy inni deklarują całkowitą niechęć do takiego powrotu.

Oczywiście, całkiem możliwe, że nieskoordynowane zbiorowe działania melomanów w rezultacie będą uprzywilejowywały jakąś formę nośników muzyki, a „neutralna” reprodukcja uczestnictwa prowadziłaby raczej do równoczesnej obecności wielu nośników. Ta sieciowość może preferować reprodukowanie takich warunków, które będą pozwalały na wielość porządków uczestnictwa i możliwość płynnego przemieszczania się między nimi, co prowadzi do kolejnej cechy kultury współczesnej. 
Frakcyjność porządków, ontologiczna złożoność kultury

Kultura jako wielość ścierających się sił, wykształcających jedynie lokalne i tymczasowo stabilne porządki, generujących anomalie, daje całościowy obraz pluralizmu. Nie jest to jednak pluralizm, o jakim mówiło się w dyskusjach wokół postmodernizmu - pluralizm wielu odmiennych elementów. Tutaj mamy do czynienia z pluralizmem porządków uczestnictwa i pluralizmem uczestnictw. Znajdujemy się więc gdzieś pomiędzy całościowym porządkiem a pluralizmem pojmowanym jako atomizacja, ale nie jesteśmy przy tym po prostu w pół drogi. Gdzie więc jesteśmy?

$\mathrm{Na}$ opisanie tej ontologicznie niezwykłej sytuacji John Law $(1997,1999)$ zaproponował pojęcie frakcyjności. Opis zjawiska zaś dała Annemarie Mol w książce The Body Multiple: Ontology in Medical Practice (2002). Na podstawie studiów nad praktykami medycznymi pisze ona o ciele, które jest czymś więcej niż jeden obiekt, ale czymś mniej niż kilka obiektów. Jest to ciało zwielokrotnione. Albo - według terminologii Lawa - ciało mające różne frakcje. Owe frakcje to różne porządki praktyk, które w teorii mogą się ze sobą sumować, jednakże w rzeczywistości wchodzą w rozmaite zależności. Zależności te tworzą złożony układ, który daje w rezultacie ontologiczną złożoność kultury.

Spróbuję trudną kwestię frakcyjności zilustrować przykładem moich badań melomanów i ewolucji nośników.

Według liniowych ujęć ewolucji nośników, płyta kompaktowa jest jednym wynalazkiem. Ma ona swoją historię. Podaje się ujednolicone daty i miejsca jej narodzin. Umieszcza się ją jako pojedynczy obiekt w cyklu ewolucyjnym. Tymczasem badani melomani rozróżniali przynajmniej trzy typy płyt CD: oryginalne kompakty, CD-ROM-y i tzw. ruskie piraty ${ }^{8}$ Teoretycznie wszystkie one stanowią jeden typ obiektu, dają się opisać za pomocą jednej zasady rejestracji informacji, prowadziły jednakże do odmiennych porządków uczestnictwa.

Na przykład niektórzy z badanych wyraźnie rozróżniali dwie pierwsze kategorie, przeznaczając im osobne półki w swoich zbiorach. Mogło to, choć nie musiało, przekładać się na wartościowanie materiału muzycznego — były płyty, których nie godziło się przegrywać, i takie, wobec których było to dopuszczalne. Niekiedy na taki podział nakładał się inny typ wartościowania o charakterze patriotycznym, według którego nie wolno było przegrywać polskich płyt.

8 Określeniem tym posługiwały się badane przeze mnie osoby. Odnosi się ono do płyt niebędących CD-ROM-ami, lecz standardowymi płytami kompaktowymi audio, zaopatrzonych $\mathrm{w}$ pełną oprawę graficzną i kupowanych na bazarach większych polskich miast od sprzedawców z reguły pochodzących gdzieś z obszarów byłego Związku Radzieckiego — stąd nazwa.. 
„Ruskie piraty” mogły być traktowane jako równorzędne $z$ innymi płytami. Niektórzy badani utrzymywali jednak, iż istnieje poważna jakościowa różnica (na minus) między nimi i płytami oryginalnymi, a także CD-ROM-ami. Niekiedy przekładało się to tylko na wzruszanie ramionami i lekceważenie tej różnicy bądź uznawanie, że jest ona wytworem wyobraźni, innym razem zaś na purystyczne omijanie takich płyt.

Podobnie same CD-ROM-y. Część melomanów traktowała je jako bezproblemową część swoich zbiorów, część zaś realizowała rozciągnięty w czasie plan wymieniania ich na płyty oryginalne. Byli też tacy, którzy po okresie zbierania CD-ROM-ów decydowali się pozbyć ich wszystkich od razu.

Czytelnikowi może się wydawać, że stosunkowo łatwo teraz sytuację opisać wydzielając po prostu trzy podtypy płyt kompaktowych. Jednak tak nie jest. Same CD-ROM-y mogły się dzielić dalej — ze względu na firmę, ze względu na kolor spodu, z racji podziału na CD-ROM-y zwyczajne i CD-ROM-y audio. Można pójść jeszcze dalej i prześledzić sposoby obecności rozmaitych wydań, edycji kolekcjonerskich, różnych remasteringów, relacji (niejednoznacznych) między płytami kompaktowymi a plikami komputerowymi i płytami analogowymi. Podziały te mogły istnieć, ale nie musiały. Prowadzi to do tego, że nie da się po prostu wydzielić typów uczestnictwa, ponieważ one same rozmaicie się wewnętrznie różnicują. Mamy, jak u Mol, jeden obiekt, ale zwielokrotniony przez otaczające go praktyki, co daje w rezultacie więcej niż jeden obiekt.

Ciekawe konsekwencje tego zróżnicowania pojawiały się wówczas, gdy porządki trzeba było negocjować, stabilizować i uwspółmierniać. Najczęściej działania takie były wymuszane przez procedury wymiany, rzadziej i może mniej dramatycznie w sytuacjach towarzyskich, gdy jedna osoba musiała wyjaśniać innym swój sposób klasyfikowania i rozdzielania form uczestnictwa. Powszechnie stosowaną bazą wymiany na przełomie wieków były spisy. Kłopot polegał na tym, że tylko część melomanów zaznaczała precyzyjnie format danej pozycji $\mathrm{w}$ zbiorach. W sytuacji niepewności pojawiały się problemy z zaufaniem na przykład jeden z rozmówców narzekał, że nie miał pewności, czy osoby, z którymi się wymieniał, respektują jego postulat, aby nie robić kopii z kopii. $\mathrm{W}$ rezultacie w praktyce zaniechał wymian.

Konsekwencje tego rodzaju wskazują na to, że wyłaniająca się złożoność świata kultury $\mathrm{w}$ znacznej mierze polega na współobecności rozmaitych porządków uczestnictwa, których łączenie wymaga oddzielnej pracy (oddzielnego „metauczestnictwa”). Porządki te mogą po prostu sumować się, warunkować — jak pokazuje Mol (2002) - mogą też, paradoksalnie, wzajemnie się zawierać lub po prostu ignorować. Ich współobecność może być rozpoznawana jako zagrożenie sprzecznością - co znów wskazuje Mol (2002) — albo bezproblemowa wielość. Mogą współistnieć czasowo obok siebie, ale też mogą wpisywać się w odmienne tempa (kolekcjonowanie płyt oryginalnych i CD-ROM-ów jako zadanie „bieżące” i jednocześnie zamienianie CD-ROM-ów jako zadanie ulokowane $\mathrm{w}$ dłuższym horyzoncie czasowym). 


\section{Wszechobecna refleksyjność}

Refleksyjność oznacza kulturowe konceptualizowanie sytuacji uczestnictwa, w jakiej aktorzy się znajdują, a także tworzenie modeli własnego otoczenia - siebie pośród innych w grupie, innych grup, otoczenia czasoprzestrzennego, aksjologicznego itd. (Giddens 2008, s. 26-31). Przy takim rozumieniu refleksyjności, istotne nie jest indywidualne roztrząsanie własnej sytuacji, lecz tworzenie kulturowych mechanizmów przypominających w jakiejś mierze pętle czy sprzężenia zwrotne. W wyniku tematyzacji danej sytuacji uczestnictwa zmienia się sama ta sytuacja, ponieważ pojawiają się $\mathrm{W}$ niej nowe elementy, które zgodnie z wcześniejszym określeniem uczestnictwa wpływają na całość sieci powiązań. Jak wskazałem wcześniej za Giddensem, nowoczesne rozpowszechnienie się systemów eksperckich wraz z procesami wykorzenienia spowodowało, że w znacznych obszarach dostęp do „świata” polega na zetknięciu się właśnie z systemami eksperckimi przez punkty dostępowe (Giddens 2008, s. 60-63), a to oznacza uczestnictwo w kulturze w znacznej mierze poprzez modele wytworzone $\mathrm{w}$ pętlach refleksyjności. Sytuacja ta do pewnego stopnia przypomina Baudrillardowski świat simulacrów, w którym rzeczywistość nawet nie jest już skrywana pod nimi, a istoty ludzkie poruszają się w nowym świecie niekończących się symulacji (zob. Baudrillard 2005). Istotną składową mechanizmów refleksyjności jest udział profesjonalnych badaczy świata - socjologów, antropologów, psychologów, dziennikarzy, artystów, pisarzy — którzy nieustannie zaludniają świat rozmaitymi aktorami (Latour 2010, s. 44-49).

Nawiasem mówiąc, skrywa się tu często mylnie rozumiany problem skuteczności czy praktyczności humanistyki (czy też humanistyki i nauk społecznych, jeśli je rozróżniamy). Naukowość tych dziedzin wiedzy nie polega, jak chciała stara filozofia nauki, na dążeniu do stworzenia matematycznych modeli. W ich przypadku tworzenie się i stabilizowanie długich sieci oddziaływan ${ }^{9}$ polega na rozpowszechnianiu się wyników ekspertyz mówiących o istnieniu takich czy innych grup (grup terapeutycznych, sekt religijnych, rozzłoszczonych klientów jakiegoś banku), pokoleń (pokolenie X, pokolenie JP II), zjawisk (kryzys ekonomiczny, kryzys demograficzny w kontekście systemu emerytalnego). Wszystkie te zjawiska łączy cecha, na którą zwróciłem uwagę w odniesieniu do pojęcia kultury - nie sposób ich uchwycić przez definicję ostensywną, toteż eksperckie nazwanie stanowi część ich ontologicznego budulca. Na tym właśnie zasadza się waga refleksyjności w kulturze współczesnej.

Mechanizmy refleksyjności nie ominęly, rzecz jasna, także melomanów. O jednym z nich wspominałem często — o dyskursywnie wytwarzanej ewolucji nośników, która przez rozmaite materialne ślady czy efekty wytwarzała w przypadku melomanów część ich kontekstu uczestnictwa. Znaczące jest jednakże

\footnotetext{
${ }^{9}$ Obraz nauki jako działalności tworzącej długie i stabilne sieci oddziaływań pojawia się w: Latour 1987.
} 
to, że pętle refleksyjności potrzebne były im $\mathrm{w}$ innych miejscach - w postaci konceptualizacji nurtów i wydarzeń muzycznych, rocznych podsumowań wskazujących na najważniejsze zdarzenia muzyczne itp. Melomani w równej mierze żyją i realizują swój projekt kolekcjonowania muzyki pośród materialnych nośników ulokowanych na półkach, jak i pośród wirtualnych światów zawierających prog rock, nową falę, IDM, free improv, ambient itp. Niekiedy te wirtualne światy przecinają się z materialnością półek i płyt na nich ustawianych, ponieważ niektórzy melomani porządkują swoje zbiory przede wszystkim właśnie ze względu na przypisanie do nurtu.

I poruszanie się pośród rezultatów cykli refleksyjności może, jak sugerowało odniesienie do Baudrillarda, nabierać własnej dynamiki, jak w przypadku gdy dyskutuje się, w jakim stopniu różne projekty jednego artysty należą do różnych nurtów muzycznych, bądź w sporach o zdefiniowanie nurtu. Można także zadać jeszcze inne pytanie: W jakim stopniu melomani rozpoznają swoją sytuację wieloletniej fascynacji muzyką i kolekcjonowania płyt poprzez jakieś eksperckie analizy? Jednakże na tym swoistym metapoziomie trudno było mi uzyskać od rozmówców jakieś konkluzywne odpowiedzi.

\section{Kultura współczesna poddana jest tyranii chwili}

Jedno było jasne podczas krążenia wokół problematyki takiego autousytuowania - świadomość zmieniających się warunków, które Thomas Hylland Eriksen (2003) nazwał zbiorczo „tyranią chwili”. Kryją się tu procesy inflacji informacyjnej, rozprzestrzenienia się i dominacji przyspieszenia i „czasu szybkiego" w kulturze oraz mechanizm jednoczesności obiegu informacyjnego. Kultura współczesna nadprodukuje informacje, co prowadzi do wielu problemów, z których podstawowy jest bodaj taki, że przyzwyczajeni raczej do radzenia sobie $z$ niedoborem informacji niż z nadmiarem nie posiadamy dobrych mechanizmów okiełznania tego ostatniego (zob. np. Eriksen 2003, s. 31-36). Na przykład o ile lekarstwem na niedobór lektur było czytanie głębokie, tak by $z$ niewielkiego tekstu wydobyć wiele, o tyle reakcją na stosy tekstów jest często bezradność, działania przypadkowe lub zdawanie się na „mądrość zbiorową" (np. listy sprzedawalności). Inną konsekwencją nadmiaru kanałów informacyjnych jest erozja tego, co wspólne, sfery publicznej, ponieważ coraz mniej jest treści podzielanych (Eriksen 2003, s. 146-170).

Przyspieszenie pozostaje sprzężone $z$ inflacją informacyjną. Więcej czynności w krótszym czasie można wykonać tylko pogarszając jakość, wykonując jedynie ich fragmenty lub robiąc kilka rzeczy na raz (Gleick 2003, s. 173-178).

Rezultaty tyranii chwili w przypadku melomanów zaobserwować jest niesłychanie łatwo. W którymś momencie każdy $z$ nich zmaga się $z$ materialnym wymiarem inflacji w postaci braku miejsca na zbiory. Niezależnie od tego, czy gromadzone są one jako płyty winylowe, płyty kompaktowe czy pliki na dysku twardym lub dyskach optycznych. Kończy się przestrzeń pokoju, miesz- 
kania, szafki czy pamięć w urządzeniach komputerowych. Jak łatwo się domyślić, istnieją rozmaite strategie radzenia sobie w tej sytuacji: jedni rozmyślnie ograniczali swoje kolekcje, dążąc do uzyskania idealnego zestawu, inni przepakowywali płyty do wydajniejszych opakowań, jeszcze inni zabierali się za montowanie kolejnego regału.

Inny efekt tyranii chwili polegał na kłopotach $z$ rozeznaniem się $w$ interesujących nurtach muzycznych, a jeśli z tym było lepiej, to gorzej wypadała sama konsumpcja płyt. To prowadziło do przeskakiwania w czas szybki - zamiast zgodnie $z$ deklarowanym ideałem słuchania całych płyt (wielokrotnie), niektóre osoby słuchały najczęściej tylko wybranych utworów (bądź utworu) bądź jedynie ich fragmentów. Innym sposobem radzenia sobie było konstruowanie wyjaśnień racjonalizujących niesłuchanie nabytych płyt (np. „zbieram na emeryturę” lub „ta płyta jest zbyt trudna, by słuchać jej często i w całości"). Jeszcze inna forma zmagań z nadmiarem to wielofunkcyjność - niektóre osoby słuchały muzyki wykonując jednocześnie inne czynności (czytanie książki, oglądanie telewizji z wyłączonym głosem itd.).

Jednym ze zjawisk charakterystycznych dla tyranii chwili obejmującej melomanów jest gonienie czasu, tak aby na początku roku następnego przygotować własne zestawienie najlepszych płyt okresu minionego (najczęściej roku, ale równie dobrze dekady czy miesiąca). Widać tu mechanizm jednoczesności informacja rozchodzi się bez opóźnień, jak pisze Eriksen, więc trzeba chwytać ją „w locie”. Znamienne było to, że wszyscy moi rozmówcy przyznawali, że nie są $\mathrm{w}$ stanie rozeznać się we wszystkich procesach na bieżąco, mimo intensywnych wysiłków.

$\mathrm{Na}$ konsekwencje życia w kulturze tyranii chwili zwracał uwagę Zygmunt Bauman w cyklu książek poświęconych płynności (np. Bauman 2006, 2007, 2008). Główną z nich jest bodaj to, że na barki uczestników spada ciężar stabilizowania zmieniającej się rzeczywistości, a to oznacza, że sami muszą stabilizować reprodukcję warunków uczestnictwa. Innymi słowy, instytucje zmieniają się tak szybko, że wpisywane w nie pierwotnie projekty jednostek okazują się od nich trwalsze i koniec końców proporcje się odwracają — to projekty stabilizują otaczający świat. Infrastruktura zmienia się szybciej niż pozornie ulotne zachcianki, a projekty są bardziej trwałe niż warunki, w jakich są realizowane.

Problem ten był wyraźnie widoczny w zmaganiach melomanów o ustabilizowanie projektu kolekcjonerstwa wobec zmieniających się technologii i pojawiania się kolejnych nośników danych. W moich rozmowach powracał problem tego, co zrobić ze zbieranymi kiedyś kasetami (choć niektórzy deklarowali, że od kaset nie odeszli i wciąż je kupuja), czy przechowywać je, czy też się ich pozbyć; czy materiał na nich zgromadzony odnawiać (kupować na płytach kompaktowych) itd. Niektórzy z badanych narzekali na upadek tradycyjnego etosu kolekcjonera i zastąpienie go nastawieniem na ściąganie pojedynczych przebojów $z$ internetu bez dbałości o integralną całość albumu muzycznego, choć jednocześnie inni wyrażali entuzjazm wobec dostępności muzyki przez internet. 
To prowadzi mnie do ostatniego już podpunktu.

\section{Rzeczy tworzą i stabilizują asymetrie w kulturze}

Choć zmieniała się infrastruktura, w którą melomani wpisywali swoje projekty — delegalizowano i zamykano nagrywalnie kaset, ważne audycje radiowe znikały $z$ anteny, odtwarzacze kompaktowe stawały się niedostępne, ogłaszano koniec płyty kompaktowej, bazary z „ruskimi piratami” kwitły i znikały, lokalne sklepy muzyczne ustępowały supermarketom i handlowi internetowemu - to udawało się utrzymywać kolekcjonerskie projekty w znacznej mierze dzięki oddelegowaniu ich do rzeczy.

Najprostszą taką delegacją były oczywiście płyty, ale później następowały kolejne. Kolekcja płyt była zamieniana na spis, a ten rozsyłany wśród znajomych lub wręcz publikowany na stronie internetowej. Sklepy internetowe same przypominały o zakupach, sprofilowany klient otrzymywał informacje o produktach, które mogą go zainteresować. Podobnie działali znajomi informujący o dostępności takich czy innych pozycji lub o koncertach ulubieńców.

Nie sposób oczywiście utrzymać na poważnie, że stabilizująca funkcja rzeczy jest charakterystyczna wyłącznie dla kultury współczesnej. Zamiast tego, można zapytać, czym współczesność różni się od przeszłości. Dwa tropy wydają się tu interesujące: rzeczy przejawiają coraz bardziej złożone kompetencje: zarówno sztuczna inteligencja sklepu internetowego, jak i znajomi robią to samo, wysyłają informację do osoby, co do której przypuszczają, że jej treść może ją zainteresować. Drugi trop, odmienny — jeśli faktycznie nasza kultura dąży do utowarowienia coraz to nowych dziedzin życia i jest to dla niej charakterystyczne, to znaczy, że wszechobecność towarów oferuje nam nowe warunki stabilizowania naszego uczestnictwa w kulturze.

Nie sposób utrzymywać, że niewielka grupka melomanów pieczołowicie kolekcjonująca płyty jest $\mathrm{w}$ stanie wskazać nam wszystkie istotne wymiary dynamiki kultury współczesnej. Jednak nie sposób również upierać się, że tradycyjne formuły uczestnictwa są $\mathrm{w}$ stanie nam je dobrze opisać. Pozostaje mieć nadzieję, że uwagi nakreślone na marginesie badania melomanów mogą złożyć się na szerszy obraz kultury współczesnej, mogą stać się jego elementem, może nawet elementem ważnym. Jeśli zaś prawdą jest, że nowoczesna kultura wspiera się na pętlach refleksyjności wytwarzanych przez systemy eksperckie, a teoria kultury do nich należy, to pora postawić kolejne pytanie: Co zmieniamy w kulturze pisząc o takim a nie innym jej obszarze? Jak naukowe uczestnictwo w kulturze wpływa na reprodukcję warunków dalszego uczestnictwa? I jeśli, podkreślę to jeszcze raz, hipotezy te są trafne, to pytania takie przestają $\mathrm{w}$ kulturze współczesnej być zbędnym kwiatkiem do kożucha 
obiektywnego poznania. Lokują się bowiem w centrum przedsięwzięć naukowych.

\section{BIBLIOGRAFIA}

Abriszewski Krzysztof, 2008, Poznanie, zbiorowość, polityka. Analiza teorii aktora-sieci Bruno Latoura, Universitas, Kraków.

Abriszewski Krzysztof, 2010a, Przemyst kulturowy jako pole sit. Dziatania melomanów i ewolucja nośników muzycznych, w: Andrzej Gwóźdź (red.), Od przemystów kultury do kreatywnej gospodarki, Narodowe Centrum Kultury, Warszawa.

Abriszewski Krzysztof, 2010b, Splatając na nowo ANT, wstęp w: Bruno Latour, Splatajac na nowo to, co spoteczne. Wprowadzenie do teorii aktora-sieci, tłum. Aleksandra Derra, Krzysztof Abriszewski, Universitas, Kraków.

Baudrillard Jean, 2005, Symulakry $i$ symulacja, tłum. Sławomir Królak, Wydawnictwo Sic!, Warszawa.

Bauman Zygmunt, 1992, Nowoczesność i zagłada, tłum. Franciszek Jaszuński, Fundacja Kulturalna Masada, Warszawa.

Bauman Zygmunt, 1995, Wieloznaczność nowoczesna, nowoczesność wieloznaczna, tłum. Janina Bauman, Wydawnictwo Naukowe PWN, Warszawa.

Bauman Zygmunt, 2000, Ponowoczesność jako źródto cierpień, Wydawnictwo Sic!, Warszawa.

Bauman Zygmunt, 2006, Płynna nowoczesność, tłum. Tomasz Kunz, Wydawnictwo Literackie, Kraków.

Bauman Zygmunt, 2007, Ptynne życie, tłum. Tomasz Kunz, Wydawnictwo Literackie, Kraków.

Bauman Zygmunt, 2008, Płynny lęk, tłum. Janusz Margański, Wydawnictwo Literackie, Kraków.

Beck Ulrich, Giddens Anthony, Lash Scott, 2009, Modernizacja refleksyjna, tłum. Jacek Konieczny, Wydawnictwo Naukowe PWN, Warszawa.

Berger Peter, Luckmann Thomas, 1986, Społeczne tworzenie rzeczywistości, tłum. Józef Niżnik, PIW, Warszawa.

Bourdieu Pierre, Wacquant Loïc J. D., 2001, Zaproszenie do socjologii refleksyjnej, tłum. Anna Sawisz, Oficyna Naukowa, Warszawa.

Callon Michel, 1986, The Sociology of an Actor-Network: The Case of the Electric Vehicle, w: Michel Callon, John Law, Arie Rip (red.), Mapping the Dynamics of Science and Technology, Macmillan Press, Houndmills.

Callon Michel, Lascoumes Pierre, Barthe Yannick, 2009, Acting in an Uncertain World: An Essay on Technical Democracy, The MIT Press, Cambridge, London.

Callon Michel, Latour Bruno, 1981, Unscrewing the Big Leviathan: How Actors Macrostructure Reality and How Sociologists Help Them To Do So, w: Karen Knorr-Cetina, Aaron V. Cicourel (red.), Advances in Social Theory and Methodology: Toward an Integration of Micro- and Macro-sociologies, Routlege and Kegan Paul, London.

Eriksen, Thomas Hylland, 2003, Tyrania chwili. Szybko i wolno ptynacy czas w erze informacji, tłum. Grzegorz Sokół, Państwowy Instytut Wydawniczy, Warszawa.

Fiske John, 1990, Ethnosemiotics: Some Personal and Theoretical Reflections, „Cultural Studies", t. 4, s. 85-98. 
Fiske John, 2005, Reading the Popular, Routlege, London-New York.

Fleck Ludwik, 1986, Powstanie i rozwój faktu naukowego. Wprowadzenie do nauki o stylu $i$ kolektywie myślowym, tłum. Maria Tuszkiewicz, Wydawnictwo Lubelskie, Lublin.

Garfinkel Harold, 2007, Studia z etnometodologii, tłum. Alina Szulżycka, Wydawnictwo Naukowe PWN, Warszawa.

Giddens Anthony, 2008, Konsekwencje nowoczesności, tłum. Ewa Klekot, Wydawnictwo Uniwersytetu Jagiellońskiego, Kraków.

Gleick James, 2003, Szybciej. Przyspieszenie niemal wszystkiego, tłum. Jacek Bieroń, Zysk i S-ka, Poznań.

Golinski Jan, 2005, Making Natural Knowledge: Constructivism and the History of Science, The Chicago University Press, Chicago.

Hastrup Kirsten, 2008, Droga do antropologii. Między teorią a doświadczeniem, tłum. Ewa Klekot, Wydawnictwo Uniwersytetu Jagiellońskiego, Kraków.

Jacyno Małgorzata, 1997, Iluzje codzienności. O teorii socjologicznej Pierre’a Bourdieu, Wydawnictwo IFiS PAN, Warszawa.

Krajewski Marek, 2010, „Uczestnictwo w kulturze jako proces uspołecznienia”, referat wygłoszony w grupie tematycznej „Obserwatoria kultury: nowe potrzeby, metody, możliwości” podczas XIV Ogólnopolskiego Zjazdu Socjologicznego w Krakowie, 8-11 września 2010.

Kuper Adam, 2005, Kultura. Model antropologiczny, tłum. Izabela Kołbon, Wydawnictwo Uniwersytetu Jagiellońskiego, Kraków.

Laet Marianne de, Mol Annemarie, 2000, The Zimbabwe Bush Pump: Mechanics of a Fluid Technology, „Social Studies of Science”, t. 30, s. 225-263.

Latour Bruno, 1987, Science in Action, How to Follow Scientists and Engineers through Society, Harvard University Press, Cambridge, Mass.

Latour Bruno, 1996, Aramis or the Love of Technology, Harvard University Press, Cambridge, Mass.

Latour Bruno, 1999, Pandora's Hope: Essays on the Reality of Science Studies, Harvard University Press, Cambridge-London.

Latour Bruno, 2010, Splatajac na nowo to, co spoteczne. Wprowadzenie do teorii aktora-sieci, tłum. Aleksandra Derra, Krzysztof Abriszewski, Universitas, Kraków.

Latour Bruno, 2011, Nigdy nie byliśmy nowocześni, tłum. Maciej Gdula, Oficyna Naukowa, Warszawa.

Law John, 1997, Heterogeneities, Department of Sociology, Lancaster University, http:// www.lancs.ac.uk/fass/sociology/papers/law-heterogeneities.pdf [16.04.2009].

Law John, 1999, After ANT: Complexity, Naming and Topology, w: John Law, John Hassard (red.), Actor Network Theory and After, Blackwell, Oxford.

Law John, 2004, After Method: Mess in Social Science Research, Routlege, London.

Lyotard Jean-François, 2010, Poróżnienie, tłum. Bogdan Banasiak, Wydawnictwo Uniwersytetu Jagiellońskiego, Kraków.

McKenzie Donald, 1990, Inventing Accuracy: A Historical Sociology of Nuclear Missile Guidance, MIT Press, Cambridge MA.

Mol Annemarie, 2002, The Body Multiple: Ontology in Medical Practice, Duke University Press, Durham-London.

Zammito John H., 2004, A Nice Derangement of Epistemes: Post-positivism in the Study of Science from Quine to Latour, University of Chicago Press, Chicago. 


\section{THE PARTICIPATION OF THE INDIVIDUAL IN CULTURE: REMARKS ON THE TOPIC OF THE NEW DYNAMICS OF CULTURE AS RELATED TO THE EVOLUTION OF MELOMANIA IN THE CONTEXT OF THE EVOLUTION OF THE MUSICAL MEDIA}

Summary

The aim of the text is to sketch the dynamics of contemporary culture, focussing on the concept of participation. General remarks are accompanied by illustrations taken from ethnographic study on music lovers faced with evolution of musical media (vinyl records, CDs, files). Following Marek Krajewski, the author rejects the traditional notion of "participation", and uses his redefinition of the term. He stresses three dimensions of cultural participation: 1. participation as socialization; 2. participation as reshaping the participants themselves, which makes material traces; 3 . participation as meta-participation, ie. the modifying of the conditions of participation. At the same time, three crucial dimensions of the notion of "culture" are taken into consideration, which enables us to analyze the participation understood in the proposed way from a triple perspective: 1. participation takes place within culture, culture enables participation to occur; 2 . culture is a resource used in the process of participation; 3 . culture as "something beyond interaction" emerges in the course of participation. The author argues that thinking of participation in this way, the contemporary culture is to be viewed as a clash between many heterogeneous forces, where constructing and maintaining stable areas is the exception rather than a rule. This is why it is so important to study of how the orders of participation are stabilized. Various forms of institutionalized reflexivity are ubiquitous in contemporary culture. Our culture is tyrannized by information, and the acceleration connected to it.

\section{Key words/słowa kluczowe}

culture / kultura; participation / uczestnictwo; modern reflexivity / nowoczesna refleksyjność; acceleration / przyspieszenie; Science and Technology Studies / studia nad nauką i technologią; evolution of music carriers / ewolucja nośników muzycznych; music lovers / melomani 